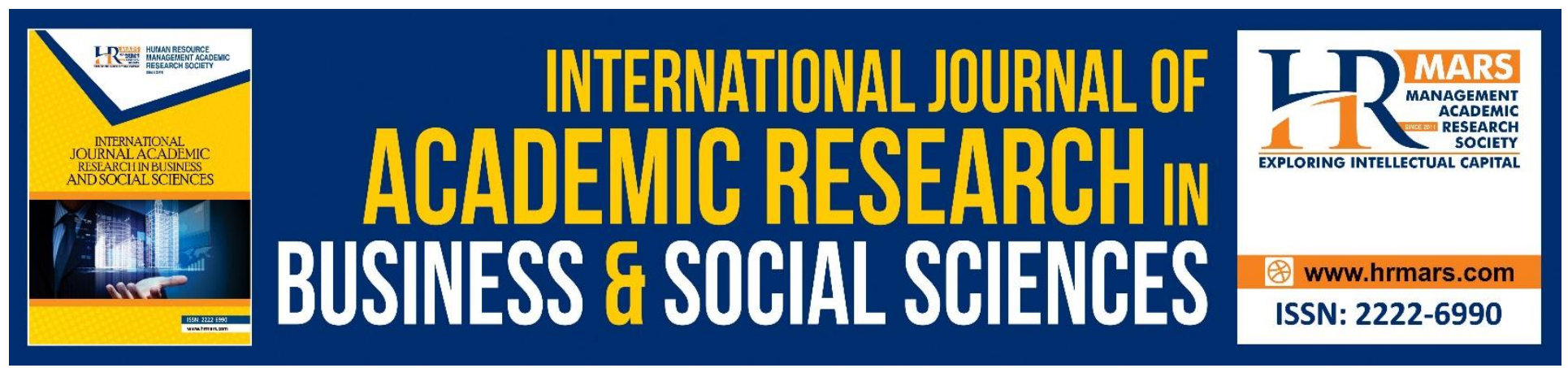

\title{
The Mediating Role of Meaningful Work between Career Growth Opportunities and Work Engagement
}

\author{
Umair Ahmed, Zainudin Bin Awang, Abu Shams Mohammad Mahmudul, \\ Hoque Benazir Ahmed Siddiqui, Abdul Samad Dahri, Habsah Muda
}

To Link this Article: http://dx.doi.org/10.6007/IJARBSS/v8-i11/5168

DOI: $10.6007 /$ IJARBSS/v8-i11/5168

Received: 11 Nov 2018, Revised: 07 Dec 2018, Accepted: 14 Dec 2018

Published Online: 16 Dec 2018

In-Text Citation: (Ahmed et al., 2018)

To Cite this Article: Ahmed, U., Awang, Z. Bin, Mahmudul, A. S. M., Siddiqui, H. B. A., Dahri, A. S., \& Muda, H. (2018). The Mediating Role of Meaningful Work between Career Growth Opportunities and Work Engagement. International Journal of Academic Research in Business and Social Sciences, 8(11), 1265-1282.

Copyright: (C) 2018 The Author(s)

Published by Human Resource Management Academic Research Society (www.hrmars.com)

This article is published under the Creative Commons Attribution (CC BY 4.0) license. Anyone may reproduce, distribute, translate and create derivative works of this article (for both commercial and non-commercial purposes), subject to full attribution to the original publication and authors. The full terms of this license may be seen

at: http://creativecommons.org/licences/by/4.0/legalcode

Vol. 8, No. 11, 2018, Pg. 1265 - 1282

http://hrmars.com/index.php/pages/detail/IJARBSS

JOURNAL HOMEPAGE

Full Terms \& Conditions of access and use can be found at http://hrmars.com/index.php/pages/detail/publication-ethics 


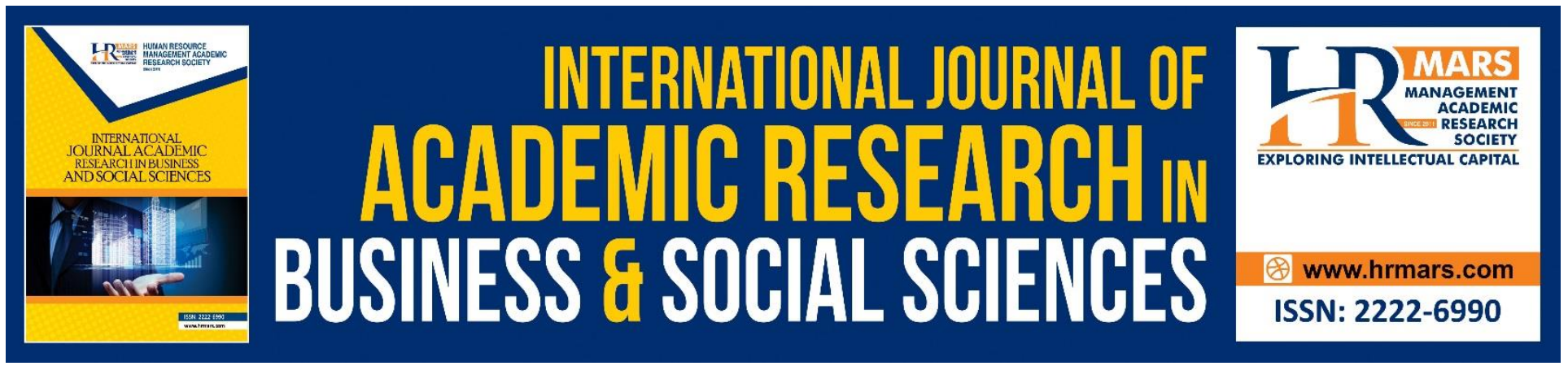

\title{
The Mediating Role of Meaningful Work between Career Growth Opportunities and Work Engagement
}

\author{
Umair Ahmed
}

School of Business Management, Universiti Utara Malaysia, Sintok, Malaysia

\section{'Zainudin Bin Awang}

Faculty of Economics and Management Sciences, Universiti Sultan Zainal Abadin,

Terengganu, Malaysia

\section{Abu Shams Mohammad Mahmudul Hoque}

Faculty of Economics and Management Sciences, Universiti Sultan Zainal Abadin,

Terengganu, Malaysia

\section{Benazir Ahmed Siddiqui}

School of Business Management, Universiti Utara Malaysia, Sintok, Malaysia

Abdul Samad Dahri

School of Business Management, Universiti Utara Malaysia, Sintok, Malaysia

\section{Habsah Muda}

Faculty of Economics and Management Sciences, Universiti Sultan Zainal Abadin,

Terengganu, Malaysia

*Corresponding Author: zainudinawang@unisza.edu.my

\begin{abstract}
Work engagement has gained much appreciation over the recent decades. Therein, multifold of research can be tracked whereby, scholars are attempting to outline and understand what possibly can predict this element of positive occupational psychology. On the similar note, the present study aimed to address a crucial research gap through examining the role of career growth opportunities towards enhancing work engagement. Accordingly, the study also strived to test the direct as well as mediating effect of meaningful work in this relationship. The self-administered questionnaire was given to some 320 randomly selected respondents from four major retail banks in Malaysia outlined
\end{abstract}


the significant positive relationship between career growth opportunities and work engagement whereby, meaningful work partially mediated their relationship. The data were analyzed using Structural Equation Modeling (SEM) in IBM-SPSS-Amos 21.0 and the stated hypotheses were tested. The study found the following direct effects are positive and significant namely, Career growth opportunities on Work engagement $(\beta=0.255, P=.001)$, Career growth opportunities on Meaningful work $(\beta=0.666, P=.000)$, and Meaningful work on Work engagement $(\beta=0.605, P=.000)$. The study also found Meaningful work partially mediates the relationship between Career growth opportunities and Work engagement. Overall, the results have landed support for meaningful work effects and its association with career growth opportunities through which organizations can help improve employees ' work engagement. The implications of the above findings are discussed.

Keywords: Career growth opportunities, Meaningful work, Work engagement, Mediation, SEM

\section{Introduction}

Growing competition has intensified the way businesses used to operate and progress. In today's economy, organizations across the globe have realized the acute importance of HRM factors through which they can potentially help maximize their outputs through bringing appropriate work behaviors. Notably, employee engagement has been recently termed as the most important prospect that businesses require these days to ensure that the workforce is full of energy, passion, and commitment towards their work (Bakker, 2011). According to Armstrong and Taylor (2014), it is essential for the enterprises to understand how to best manage its workforce for strategic sustenance as human resources are the only element that could help to bring competitive advantage to the business at present times. Importantly, organizational scholars have realized that in today`s global economy, what pushes people the most to give their best towards work more than anything else is career growth opportunities (Bedarkar \& Pandita, 2013). However, there is a dearth of research pertaining to how career growth opportunities can foster work engagement Ahmed, Majid, \& Zin, 2016). The present study hence attempted to examine how career growth opportunities can possibly explain work engagement. Accordingly, how meaningfulness of work can likely intervene in this relationship for a more responsive understanding of the relationship.

\section{Literature Review \\ Work Engagement}

Notable literature has defined work engagement as a positive work based state that enables an individual to work with energy, passion, and immersion (Schaufeli et al; 2002). People who are engaged at work are termed to be highly resilient and tend to give their best towards work prospects (Bakker \& Schaufeli, 2008). There is a growing array of research that has outlined work engagement being the most important employee behavior for organizational success, profitability and productivity (Sorenson, 2013). Work engagement is an intrinsic motivation prospect that facilitates an individual to work harder than other and showcase willingness to offer more discretionary efforts. According to Rich et al. (2010) engaged people to connect themselves with the work due to which, they showcase energy and enthusiasm towards the work. People who are engaged, the work becomes an element of a personal job for them which is why they immerse in the assigned tasks completely (Bakker \& Demerouti, 2008). Thus, one can outline the acute importance and the 
potential level of significance for organizations to have work engaged people. The literature also outlines how significant such prospects could be especially for businesses aiming to compete in tough business clusters and demographic settings.

According to Salanova, Agut, and Peiro (2005), businesses today that are focused on harnessing employee work behaviors for profound outcomes should focus on work engagement. Such people are emotionally charged and psychologically connected with the work which makes them express high enthusiasm at work. As a consequent even, one can see a variety of different benefits of work engagement such as Saks (2006) has outlined that engaged employees showcase citizenship behaviors whereby, Bellon et al. (2010) reported them being loyal and job satisfied. Accordingly, Britt, Adler, and Bartone (2001) found work engaged people being better at tackling stress compared to ones who weren't. This evidence leads us to assert that work engagement is beyond conventional positive employee behaviors like commitment and motivation as it fuels to serve with discretionary efforts with high passion, immersion, and resilience. Based on this, it becomes more important for organizational scholars to understand work engagement and its prediction in order to forwards better implications for individuals in practice.

\section{Career Growth Opportunities}

Prominent scholars in their efforts towards exploring the antecedents of work engagement have highlighted the prominent influence of job resources (Demerouti et al., 2001). They include job, individual or organizational factors that help and facilitate employees to shape right work behaviors (Bakker, 2011). Conservation of Resources theory (Hobfoll, 1989) is often underpinned to explain this which suggests that employees value resources and aim to accumulate them as they help them to shape positive behaviors. As per Ling Suan and Nasurdin (2014), one of the important resources in this aspect are HR factors and career growth opportunities is one of the prominent ones.

Kraimer and Wayne (2004) have defined career growth opportunities as HR prospects that cater to career development needs of an employee. Career growth opportunities have been termed as prominent for harnessing employees positive work behaviors whereby, positive employee views in this regard can make a considerable impact on their productivity and performance.

Studies have outlined significance boosting the impact of career growth opportunities on career satisfaction, performance, turnover, and job satisfaction (Barnett \& Bradley, 2007; Bedarkar \& Pandita, 2013; Cordero, DiTomaso, \& Farris, 1994; Chen et al., 2003). These studies have outlined that career growth opportunities employees to view their work being significantly acknowledging and worthwhile. These evidences also indicate that, through the responsive availability of career growth opportunities for employees, organizations can motivate employees to work with focus, commitment, energy, and dedication to result in mutual benefits.

\section{Meaningful Work}

Theoretical understandings on employee wellbeing have outlined the rigorous impact of meaningful work on employee outcomes and behaviors. Meaningful work denotes to employee perception about the work/assigned tasks being worthy, valuable and significant (Hackman \& Oldham, 1976). The construct is principally the judgment of individuals regarding their work to be important whilst serving some purpose (Rosso, Dekas \& Wrzesniewski, 2010). An employee is likely to involve in the 
work with whole heartedness when he/she perceives the work to be of significant contribution to oneself and organization at large. People who are found viewing their work to be meaningful have resulted with high work motivation and organizational commitment (Chalofsky \& Krishna, 2009; Steger, Dik \& Duffy, 2012).

\section{Career Growth Opportunities and Work Engagement}

The literature on work engagement has outlined limited studies pertaining to career growth opportunities hence, indicating towards dearth of research in this regards. However, few study including Poon (2013) is prominent in this aspect whereby, the author examined employees from a public sector university and found a positive relationship between career growth opportunities and work engagement. A little earlier, Mckechnie, and Swanberg (2011) has also reported the significant positive relationship between the two amongst the retail employees in the USA. Similar findings were also reported by Barbier et al. (2012), highlighting the strategic significance of career growth opportunities and work engagement. Accordingly, the study has recommended for a thorough investigation to underline its short-term as well as long-term influences upon individual engagement at work. Fairlie (2011) accordingly has asserted that career growth opportunity is one of the overlooked sources of work engagement hence, requires empirical attention.

Empirical evidences outlined above highlight that there is a significant impact of career growth opportunities on employees' wellbeing and one can conveniently understand how it can make a strategic impact on business performance and productivity through fostering engagement at work. Sadly, there is little known and understood whereby, how and to what length, this relationship is of value in various other occupational setting and demographic locations is still unclear thus, requiring further empirical attention (Ahmed, Majid, \& Zin, 2016b; Sahoo \& Sahu, 2009; Rothmann \& Joubert, 2007). Hence, the present study formulated to test the following hypothesis:

H1: Career growth opportunities has a positive and significant effect on Work Engagement.

\section{Career Growth Opportunities and Meaningful Work}

Fairlie (2011) in his notable study has outlined that career opportunities are one of the important prospects through which employees view their work to be meaningful. Through empirical evidence, the author has asserted that organizational scholars need to work on developing places with a good number of career advancement opportunities in order to enhance their meaningfulness perceptions. Baldwin (1990) has outlined that developing a career based approach for employees to learn, develop and grow further can be of prominent value to help them establish a better sense of the work and organization. Accordingly, Thatcher et al. (2006) outlined that when employees are provided with opportunities to learn and grow, they view the work to be meaningful hence, the present study formulated the following hypothesis:

H2: Career Growth Opportunities has a positive and significant effect on Meaningful Work.

\section{Meaningful Work and Work Engagement}

As outlined earlier, meaningful work is an individual's perception of the work being important and contributory (Shuck \& Rose, 2013). Though the literature has outlined paucity of research in the area (Fairlie, 2011), yet still; few studies could be highlighted. A study by Fairlie (2011) has outlined that 
meaningful work is of great prominence for work engagement prediction. The study also outlined that people that viewed their work to be meaningful were responsive in enhancing their work engagement. Accordingly, Rothman and Buys (2011) in their study found that meaningful work perceptions were important for employees to develop their engagement at work. The study also outlined that meaningful work perceptions harnessed employees to boost their psychological resources and work with higher dedication and commitment thus, showcasing work engagement. Similar results were also reported by Stringer and Broverie (2007), outlining individuals perceiving their work as contributory and significant were capable of harnessing their personal selves to work with higher energy, more discretionary efforts and immersion thus, showcasing work engagement. These important yet limited empirical confirmations thus outline that there is a prominent role that meaningful work can play which thus needs to be given due attention. Fairlie (2011b) asserted that meaningful work is a sleeping giant which is yet to be realized by the scholars and practitioners pertaining to its acute importance for shaping positive employee behaviors. Hence, the present study formulated the following hypothesis:

H3: Meaningful work has a positive and significant effect on Work Engagement.

\section{Mediation of Meaningful Work in Career Growth Opportunities and Work Engagement Relationship}

Engagement literature have outlined Mediation of several factors for instance; Salanova, Agut, and Peiro (2005) examined the mediation of service climate between numerous job resources and work engagement. Similarly, efficacy beliefs were found to mediate the relationship between transformational leadership and work engagement in the study by (Salanova, Lorente, Chambel, Martinez, 2011). In parallel, meaningful work has been termed as a notable mediator between different perception based work prospects (Alfes, Shantz, Truss, Rees, \& Gatenby, 2013). Thus, the present study assumed that availability of career growth opportunities would potentially ignite a sense of meaningfulness via harness work wellbeing thus result in causing work engagement. Therefore, the following hypothesis was formulated:

H4: Meaningful work mediates the relationship between career growth opportunities and work engagement. 


\section{The Conceptual Framework of the study}

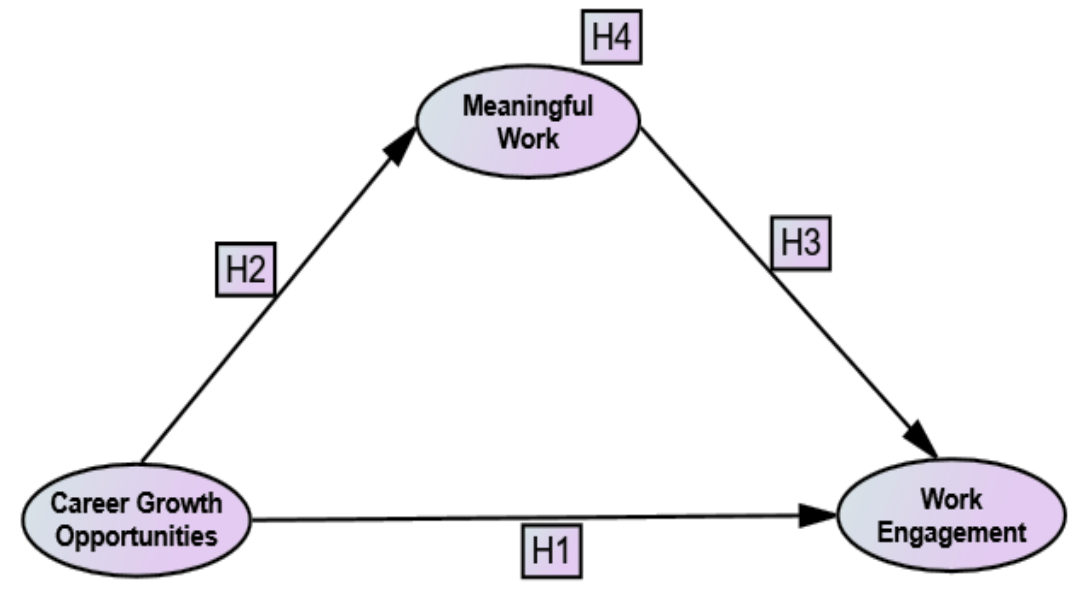

Figure 1: Research Framework

\section{RESEARCH METHODOLOGY}

The purpose of this research is to investigate the relationship of CGO and WE with $\mathrm{MW}$ as a mediator. Therein, perceptions of employees from four major retail banks were obtained to analyze the relationships. The retail branches of the bank were in Perlis, Kedah, Penang, Perak, and Terengganu from the Malaysian Peninsula were targeted.

\section{Sample and Data Collection}

The survey was conducted on employees working in the four major retail banks in Malaysia working in various positions in the service branches. A self-administered questionnaire was randomly distributed to employees during the month of February 2017. Humble reminders through email were made to ensure maximum response rate. Keeping the complex and tough work structures of banking sector beforehand, the respondents were given a total of 45 days to fill the questionnaire. A total of 320 usable questionnaires were received back. Grounded on gender, male constituted $61 \%$ while female represented $39 \%$ of the sample population.

\section{Operationalization and Instrumentation}

The survey consisted of measures to obtain data pertaining to work engagement, carer growth opportunities, and meaningful work. Based on the explanations of Schaufeli et al. (2002), the current study operationalized work engagement as positive work based disposition that evokes energy and passion to perform for highly positive outcomes. Therein, work engagement was assessed through 6item engagement scale (Schaufeli, Bakker, \& Salanova 2006). The scale has been deployed in a variety of different occupational and geographical settings including Asia, Europe, Africa and North America (Shimazu et al., 2008; Storm \& Rothmann, 2003; Tat \& Ng, 2012; Seppala et al., 2009; Nerstad, Richardsen, \& Martinussen, 2010; Xanthopoulou et al., 2009; Salanova, Agut, \& Peiro, 2005; Chaudhary, Rangnekar, \& Barua, 2012. Accordingly, the present study operationalized career growth opportunities based on the explanations of Kuvaas (2008) as the availability of career growth 
INTERNATIONAL JOURNAL OF ACADEMIC RESEARCH IN BUSINESS AND SOCIAL SCIENCES

Vol. 8, No. 11, Nov, 2018, E-ISSN: 2222-6990 @ 2018 HRMARS

prospects and promotion opportunities in the business. 4-item scale by Kuvaas (2008) was used to examine employees ' perceptions pertaining to available career growth and development prospects. Lastly, following the elaboration of Hackman and Oldham (1976), meaningful work was operationalized as perceptions of employees about the work as valuable and contributory. The direct and mediating effect of meaningful work was assessed through 6-item scale by Ashmos and Duchon (2000). Respondents were made to respond and rate using 7-point interval scale with 1 denoting to strongly disagree and 7 as strongly agree.

\section{Method of Analysis}

SEM is a Second Generation method of multivariate analysis technique developed to cater limitations in the traditional Ordinary Least Squares (OLS) especially when dealing with latent constructs (Kashif et al., 2016; Mohamad et al., 2016; Yusof et al., 2017). The analysis for latent constructs is no longer appropriate with traditional OLS (Awang, 2014; 2015; Awang et al., 2015). Thus the researchers need to employ SEM so as to keep pace with the advancement in research methodology. Not only that, using IBM-SPSS- AMOS software, the researcher could convert their theoretical framework directly into the Amos Graphics for analysis. In SEM, the researcher validates the measurement model of a latent construct using the Confirmatory Factor Analysis (CFA) procedure. Once validated, the researcher could assemble the constructs into the structural model and execute the Structural Equation Modeling (SEM) procedure (Kashif et al., 2016; mohamad et al., 2016; Yusof et al., 2017). Consequently, analyzing and testing the theory using IBM-SPSS-AMOS software is fast, efficient and robust (Awang, 2014; 2015). Hence, this study will employ IBM-SEM-AMOS software package for this study.

\section{RESULTS}

\section{Measurement Model}

Prior to modeling the structural model and executing SEM, the study needs to validate the measurement model of latent constructs for unidimensionality, validity, and reliability (Hoque et al., 2017; Awang et al.2015). Unidimensionality is achieved when the factor loading for all items are positive with a minimum value of 0.6 (Hoque et al., 2017a; Hoque and Awang, 2016). The Construct Validity is achieved when the fitness indexes for the measurement model meet three model fit categories namely, Absolute Fit, Incremental Fit, and Parsimonious Fit. The Discriminant Validity is achieved when all constructs are not highly correlated. The Convergent Validity is achieved when the value of Average Variance Extracted (AVE) meet the minimum value of 0.5 (Hoque et al., 2017a; Hoque and Awang, 2016). The Construct Reliability is achieved when the values of Composite Reliability (CR) and Average Variance Extracted (AVE) reach the minimum value of 0.6 and 0.5 respectively (Hoque et al., 2017; Hoque et al., 2017a). The Internal Reliability among the items is achieved when the value of Alpha Cronbach reaches the minimum value of 0.7 (Hoque and Awang, 2016). The fitness indexes shown in Figure 2 indicate the measurement model of the three latent constructs (CGO, MW, and WE) have met the requirement for Construct Validity. 
INTERNATIONAL JOURNAL OF ACADEMIC RESEARCH IN BUSINESS AND SOCIAL SCIENCES Vol. 8, No. 11, Nov, 2018, E-ISSN: 2222-6990 @ 2018 HRMARS

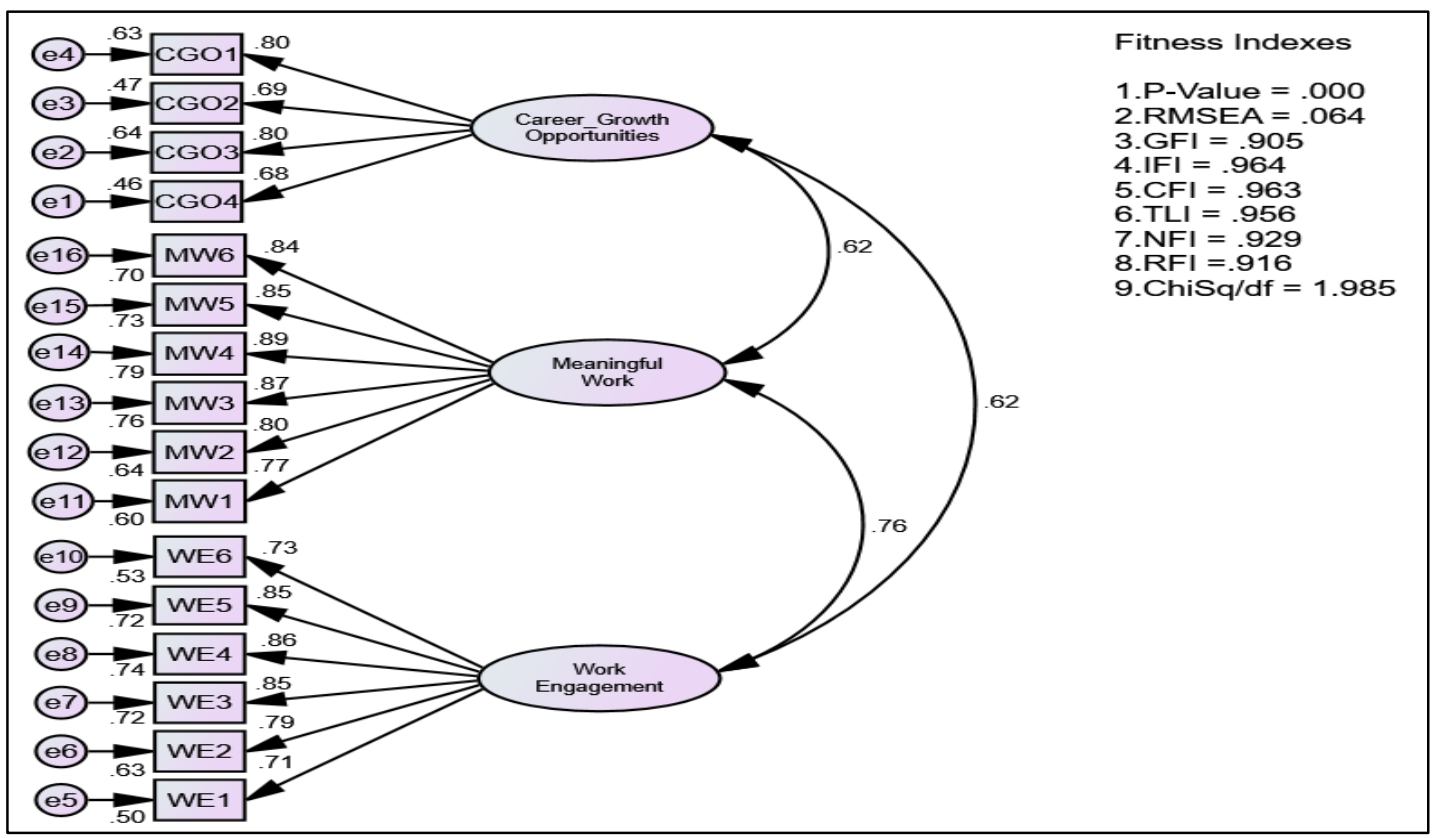

Figure 2: The Pooled CFA Results and the Output Showed All Fitness Indexes Achieved

The values of factor loading for every item together with the Cronbach Alpha, CR and AVE for every construct as shown in Table 1 indicates all latent constructs (CGO, MW, and WE) have achieved Convergent Validity, Construct Reliability and Internal Reliability.

Table 1: The CFA Results for the Measurement Model

\begin{tabular}{|c|c|c|c|c|c|}
\hline Construct & Item & $\begin{array}{l}\text { Factor } \\
\text { Loading }\end{array}$ & $\begin{array}{c}\text { Cronbach } \\
\text { Alpha }\end{array}$ & CR & AVE \\
\hline Career & CGO1 & 0.80 & \multirow{4}{*}{.822} & \multirow{4}{*}{0.852} & \multirow{4}{*}{0.592} \\
\hline Growth & CGO 2 & 0.79 & & & \\
\hline Opportuniti & CGO 3 & 0.80 & & & \\
\hline es (CGO) & CGO 4 & 0.68 & & & \\
\hline \multirow{6}{*}{$\begin{array}{l}\text { Meaningful } \\
\text { Work (MW) }\end{array}$} & MW1 & 0.77 & \multirow{6}{*}{.933} & \multirow{6}{*}{0.934} & \multirow{6}{*}{0.702} \\
\hline & MW2 & 0.80 & & & \\
\hline & MW3 & 0.87 & & & \\
\hline & MW4 & 0.89 & & & \\
\hline & MW5 & 0.85 & & & \\
\hline & MW6 & 0.84 & & & \\
\hline \multirow{6}{*}{$\begin{array}{l}\text { Work } \\
\text { Engagement } \\
\text { (WE) }\end{array}$} & WE1 & 0.71 & \multirow{6}{*}{.911} & \multirow{6}{*}{0.914} & \multirow{6}{*}{0.641} \\
\hline & WE2 & 0.79 & & & \\
\hline & WE3 & 0.85 & & & \\
\hline & WE4 & 0.86 & & & \\
\hline & WE5 & 0.85 & & & \\
\hline & WE6 & 0.73 & & & \\
\hline
\end{tabular}


The Discriminant Validity is assessed through correlation and also through Discriminant Validity Index Summary. According to Awang et al. (2015), one of the criteria for Discriminant Validity is the correlation between exogenous constructs must not exceeded 0.85 . Another criterion is through the Discriminant Validity Index Summary as shown in Table 2. The diagonal value is the square-root of AVE for the respective constructs, while other values are the correlation between constructs. The Discriminant Validity of the constructs is achieved when the diagonal values are greater than any values in their rows, and columns respectively.

Table 2: Discriminant Validity Index Summary

\begin{tabular}{|c|c|c|c|}
\hline Construct & $\begin{array}{c}\text { Career Growth } \\
\text { Opportunities (CGO) }\end{array}$ & $\begin{array}{c}\text { Meaningful } \\
\text { Work (MW) }\end{array}$ & $\begin{array}{c}\text { Work } \\
\text { Engagement } \\
\text { (WE) }\end{array}$ \\
\hline $\begin{array}{c}\text { Career Growth Opportunities } \\
\text { (CGO) }\end{array}$ & $\mathbf{0 . 7 6 9}$ & & \\
\hline Meaningful Work (MW) & 0.625 & $\mathbf{0 . 8 3 7}$ & $\mathbf{0 . 8 0 0}$ \\
\hline Work Engagement (WE) & 0.618 & 0.755 & \\
\hline
\end{tabular}

The correlation value of latent constructs CGO and MW is 0.625 , the correlation value of latent constructs $C G O$ and $W E$ is 0.618 and correlation value of $M W$ and $W E$ is 0.755 . As the value in diagonal is greater than any values in its row and column, this study accomplishes that the discriminant validity is achieved for the model (Kashif et al., 2016; Mohamad et al., 2016; Yusof et al., 2017).

\section{Structural Model}

As shown in Figure 3, three hypotheses $(\mathrm{H} 1, \mathrm{H} 2, \& \mathrm{H} 3)$ are supported. In $\mathrm{H} 1$, Career Growth Opportunities has a significant direct effect on Work Engagement $(\beta=0.255, P=.001)$. In $H 2$, Career Growth Opportunities has a significant direct effect on Meaningful Work $(\beta=0.666, P=.000)$, in $H 3$, where Meaningful Work also has a significant direct effect on Work Engagement $(\beta=0.605, P=.000)$. The structural model explains $61 \%$ variance in Work Engagement. 


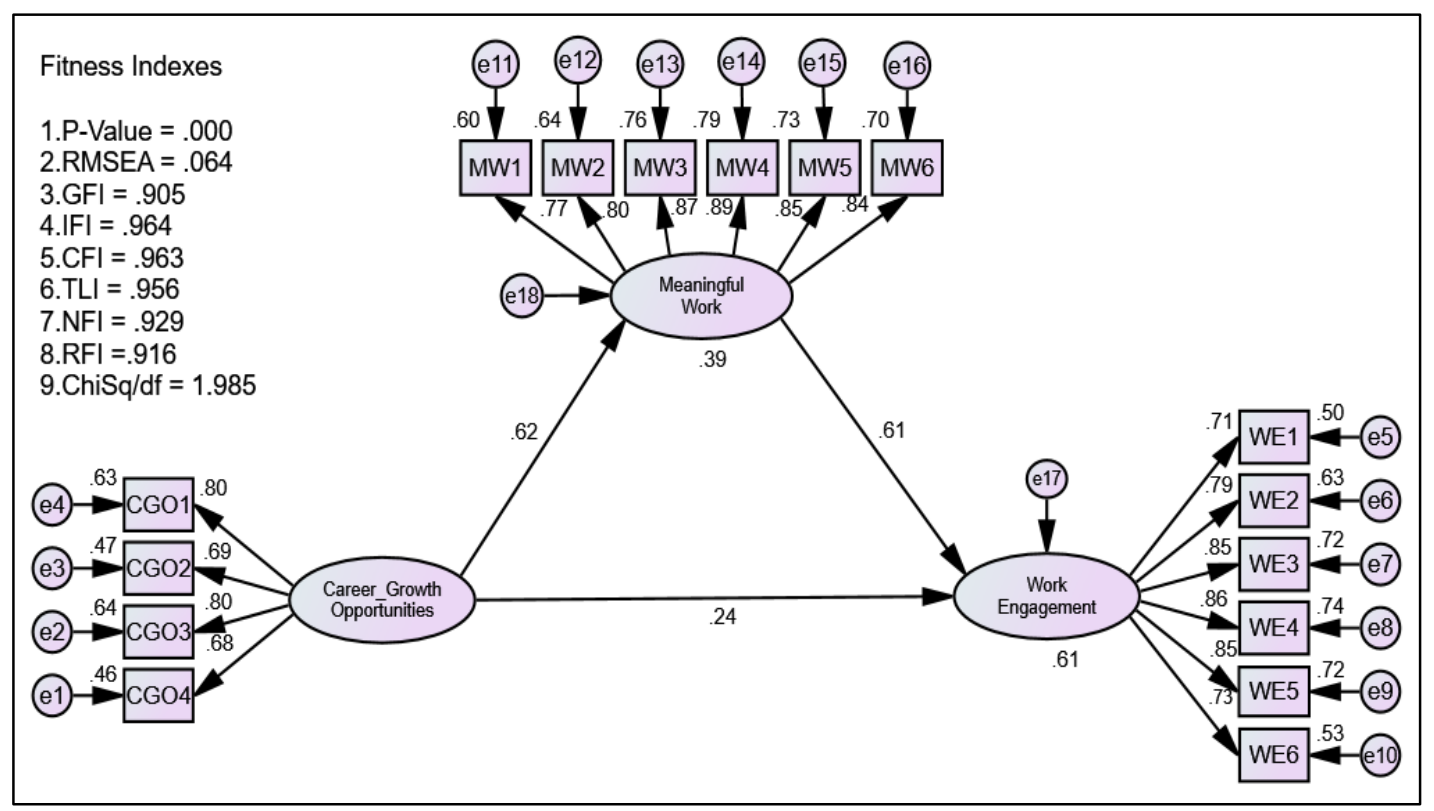

Figure 3: The Standardized Regression Weights for Every Path in the Model

\section{Test of Mediation}

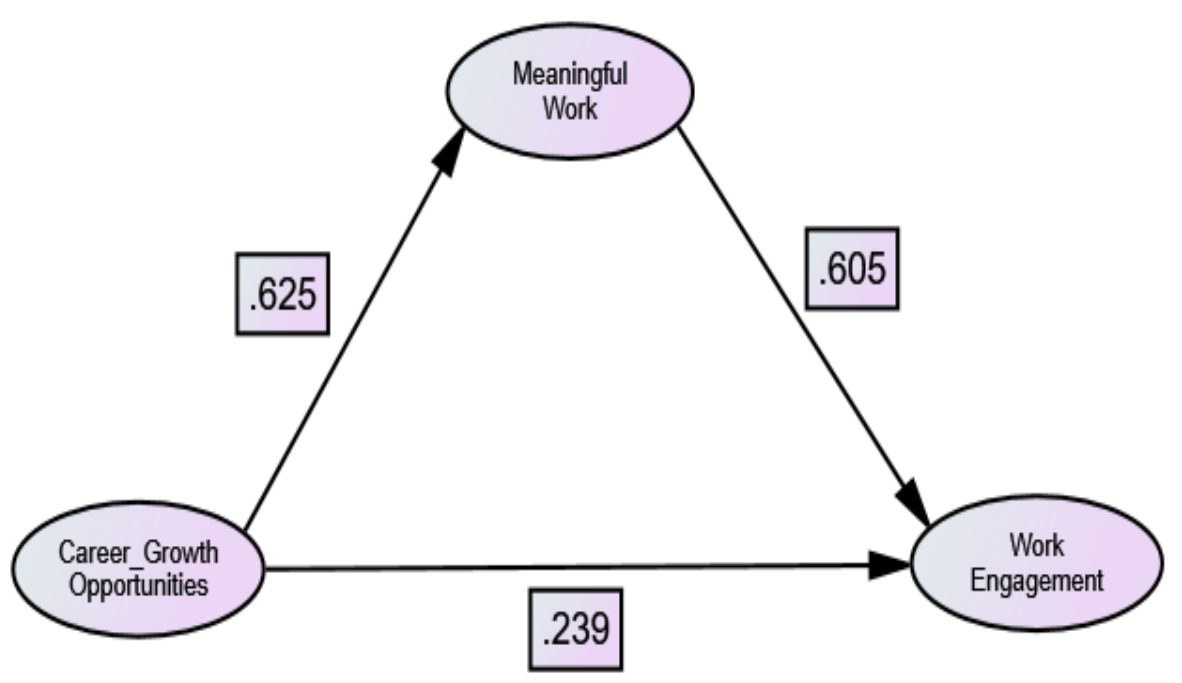

The Indirect Effect $=0.625 \times 0.605=0.378$ and the Direct Effect $=0.225$. Since Indirect Effect is greater than Direct Effect, and both Indirect path (CGO to MW and MW to WE) are significant, partial mediation occurs (Kashif et al., 2016; Mohamad et al., 2016; Yusof et al., 2017).

As a result, Meaningful Work partially mediates the relationship between Career Growth Opportunities and Work Engagement since the indirect effect is higher than the direct effect and the direct effect is still significant after mediator enters the model (Kashif et al., 2016; Mohamad et al., 2016; Yusof et al., 2017). 
INTERNATIONAL JOURNAL OF ACADEMIC RESEARCH IN BUSINESS AND SOCIAL SCIENCES Vol. 8, No. 11, Nov, 2018, E-ISSN: 2222-6990 @ 2018 HRMARS

\section{Confirming the Mediation Result Through Bootstrapping}

It is imperative to reconfirm the result of the mediation test using the re-sampling procedure known as bootstrapping to reconfirm the hypothesis testing result of indirect effect (Hair et al., 2010; Awang, 2015; Awang et al., 2015). The process allows for sampling with replacement between 500-5000 samples from the existing dataset. The study could compare the bootstrapping results with the results using normal modeling procedure. If there is any difference between the two, then the bootstrapping result will be admitted. The bootstrapping result with $n=1000$ and bias-corrected confidence interval 0.95 is shown in Table 3.

Table 3: The Summary of Bootstrapping Result

\begin{tabular}{|c|c|c|}
\hline & Indirect Effect & Direct Effect \\
\hline Bootstrapping Results & 0.378 & 0.239 \\
\hline Does mediation occur? & \multicolumn{2}{|c|}{$\begin{array}{l}\text { The mediation occurs since the indirect effect is } \\
\text { greater than direct effect }\end{array}$} \\
\hline Bootstrapping $p$-value & 0.001 & 0.004 \\
\hline Results & Significant & Significant \\
\hline Type of Mediation & \multicolumn{2}{|c|}{ Partial Mediation since the direct is still significant. } \\
\hline
\end{tabular}

Table 3 shows the beta estimate of both the indirect effect and direct effects of Career Growth Opportunities on Work Engagement $(\beta)=0.366$ and 0.225 respectively. Furthermore, it shows the $P$ value of indirect and direct effects for the Career Growth Opportunities on Work Engagement ( $P$ value $=0.001$ and 0.004 respectively). Based on the bootstrapping results in Table 3, it is evident that Meaningful Work partially mediates the relationship between Career Growth Opportunities on Work Engagement. Consequently, the $\mathrm{H}_{4}$ of this study which posited that Meaningful Work mediates the relationship between Career Growth Opportunities on Work Engagement is also supported by the data of this study.

\section{Discussion and Implications for Theory and Practice}

The present study aimed to outline the relationship between career growth opportunities work engagement followed by the mediation of meaningful work in their relationship. The study results have found a significant positive relationship between career growth opportunities and work engagement thus, confirming hypothesis 1. The results are parallel to Barbier et al. (2013); Fairlie (2011); and Mckechnie, and Swanberg (2011) outlining that employees perceiving positive about the available career growth opportunities in terms of development, promotion and career progression were able to harness their psychological wellbeing to connect with energy and immersion at work thus, predicting work engagement. The results have extended our theoretical understanding and knowledge pertaining to the positive influence of career growth opportunities upon individual 
psychological wellbeing (work engagement) (Arnold, Turner, \& Barling, 2007). Accordingly, perceptions about the work being meaningful were also found to be explaining this relationship hence it suggests that meaningful work perceptions are important for enhancing employees ' work engagement. Overall, the results have landed support for meaningful work effects and its association with career growth opportunities through which organizations can help improve employees ' work engagement. The findings have outlined that employees connect career growth opportunities as a source of viewing their work is meaningful. In simple, providing career growth opportunities to a certain extent can help employees to enhance their perceptions about the work being worthy, significant and contributory which leads them to enhance their work engagement. In the similar vein, the findings are connected with the idea of developing such prospects that could help employees to view their work as full of career development and growth opportunities in order to enrich their work engagement and meaningful work can play an active role in it.

The findings of the present study have several theoretical and practical implications to forward. Concerning to theoretical, the present study has extended our understanding pertaining to conservation of resources theory, outlining the critical role of resources in shaping employee behaviors. Under its explanations, the present study has also forwarded consonance to the assertions of Ling Suan and Nasurdin (2014), by finding career growth opportunities as an important developmental job resource. Accordingly, the study has outlined that career growth opportunities are of prominent value when it comes to work engagement prediction. This, thus, sheds light on the new arena of HR focused scholars to realize and understand what further empirical associations they could possibly bring towards the concept of engagement and its enhancement. Likewise, the findings highlight an important arena for HR practitioners to focus and unleash how through providing effective career growth opportunities, they can make employees work with immersion, dedication, and energy. Similarly, policy makers can also play a notable role when it comes to harnessing employees' work engagement. Therein, organizations can attempt to ensure there is an ample number of growth and development opportunities for employees to grow and move up the ladder in order to enhance their positive self. Accordingly, there is a need for major facilitation from top authorities to help establish career growth prospects for employees to ensure they develop the positive perceptions about the work and in relation to the psychological wellbeing.

In parallel, the present study has outlined that meaningful work is essential and crucial for employees in order to give their best thus showcase work engagement. The study has outlined a new arena of research for engagement enthusiastic researchers to see how meaningful work can help to explain several other empirical relationships concerning to other HR prospects. Likewise, the findings forward implications for policy makers to focus on prospects that could make them feel that the work that they are doing is contributory and significant for themselves as well as organizations at large. As Fairlie (2011b) has asserted that meaningful work is a sleeping giant that the scholars are yet to understand in terms of its direct and intervening effects. The present study has made a notable stride and outline that meaningful work can be a healthy intervening role when it comes to career growth and work engagement relationship. 


\section{Limitations and Scope for Future Studies}

Despite significant results and notable implications, the present also has some important limitations. At first, the study used cross-sectional research design which at times restricts from drawing causal explanations. In this regard, longitudinal research study could be a prominent arena for future scholars on the framework to see how career growth opportunities link with work engagement following the mediation of meaningful work and strengthen the findings of the present study as well. Furthermore, the present study used self-reporting measures due to which there is a possibility of having inflated relationships between career growth opportunities, meaningful work, and work engagement. Although, studies in the past examining work engagement can be traced deploying similar approach (Xanthopoulou, Bakker, \& Fischbach, 2013; Xanthopoulou et al., 2009) yet still; there is a likelihood that the sample of the present study may have under-reported work engagement. Though, the present study attempted to minimize these issues through ensuring that the anonymity of the scales (Podsakoff, Mackenzie, Lee, \& Podsakoff, 2003).

Also, the findings have limited generalizability as the present study catered to employees working in four large retail bank in Malaysia. Future studies, therefore, may work on focusing on other occupational settings. Comparative studies could be another arena for future scholars to see how the examined factors including career growth opportunities and meaningful work result towards predicting work engagement. Likewise, the study can be replicated upon employees from other banks also to see how they perceive career growth opportunities and how influence on employees 'work engagement following the mediation of meaningful work. In addition, to this, it is essential to understand that there is a need for robust underlining of prospects that could help boost employees ' meaningful perceptions to the maximum level to result in higher engagement. Accordingly, since the present study only examined career growth opportunities, future scholars may attempt to test the impact of other HR prospects like training, performance appraisal and compensation upon work engagement and how whether or not meaningful work intervenes in their association.

\section{Conclusion}

The present study has provided empirical confirmation towards the concept of work engagement through outlining how career growth opportunities can contribute and meaningful work can intervene. The study found a positive relationship between career growth opportunities and work engagement whereby, it also found meaningful work partially mediating this relationship. In broad, the findings provide evidence to support the explanations of conservation of resources theory and how individual positive behaviors could be shaped. The study has also forwarded important implications for scholars and practitioners to help facilitate their understanding and comprehension regarding career growth opportunities, work engagement, and meaningful work perceptions. The findings have empirically strived to guide HR policy makers and engagement enthusiasts to evidently see the role of providing growth prospects and assigning contributory work to employees to help them boost engagement at work. 
INTERNATIONAL JOURNAL OF ACADEMIC RESEARCH IN BUSINESS AND SOCIAL SCIENCES

Vol. 8, No. 11, Nov, 2018, E-ISSN: 2222-6990 @ 2018 HRMARS

\section{References}

Ahmed, U., Majid, A. H. A., \& Zin, M. L. M. (2016a). HR Moderating HR: Critical link between Developmental HR Practices and work engagement in a Moderated Model. Management Review: An International Journal, 11(2), 4-22.

Ahmed, U., Majid, A. H. A., \& Zin, M. L. M. (2016b). Meaningful Work and Work Engagement: A Relationship Demanding Urgent Attention. International Journal of Academic Research in Business and Social Sciences, 6(8), 116-122.

Alfes, K., Shantz, A., Truss, C., \& Soane, E. (2013). The link between perceived human resource management practices, engagement and employee behaviour: a moderated mediation model. The International Journal of Human Resource Management, 24(2), 330-351.

Armstrong, M., \& Taylor, S. (2014). Armstrong's handbook of human resource management practice: Kogan Page Publishers.

Awang, Z. (2014). A Handbook on SEM for Academicians and Practitioners: the step by step practical guides for the beginners. Bandar Baru Bangi: MPWS Rich Resources.

Awang, Z. (2015). SEM made simple: A Gentle Approach to Learning Structural Equation Modeling. Bandar Baru Bangi: MPWS Rich Resources.

Awang, Z., Afthanorhan, A., Mohamad, M., and M. A. M. Asri, M. A. M. (2015). An evaluation of measurement model for medical tourism research: the confirmatory factor analysis approach, International Journal of Tourism Policy, 6(1), 29-45.

Bakker, A. B., \& Demerouti, E. (2008). Towards a model of work engagement. Career Development International, 13(3), 209-223.

Bakker, A. B., \& Schaufeli, W. B. (2008). Positive organizational behavior: Engaged employees in flourishing organizations. Journal of Organizational Behavior, 29(2), 147-154.

Bakker, A. B., Albrecht, S. L., \& Leiter, M. P. (2011). Key questions regarding work engagement. European Journal of Work and Organizational Psychology, 20(1), 4-28.

Baldwin, R. G. (1990). Faculty career stages and implications for professional development. Enhancing faculty careers: Strategies for development and renewal, 20-40.

Barbier, M., Hansez, I., Chmiel, N., \& Demerouti, E. (2013). Performance expectations, personal resources, and job resources: How do they predict work engagement? European Journal of Work and Organizational Psychology, 22(6), 750-762.

Barnett, B., \& Bradley, L. (2007). The impact of organisational support for career development on career satisfaction. Career Development International, 12(7), 617-636

Bedarkar, M., \& Pandita, D. (2013). A Study on the Drivers of Employee Engagement Impacting Employee Performance. Procedia-Social and Behavioral Sciences, 133(2014), 106-115.

Bellon, J. S., Estevez-Cubilete, A., Rodriguez, N., Dandy, R., Lane, S., \& Deringer, E. (2010). Employee engagement and customer satisfaction. Paper presented at the Allied Academies International Conference. Academy of Health Care Management. Proceedings.

Britt, T. W., Adler, A. B., \& Bartone, P. T. (2001). Deriving benefits from stressful events: the role of engagement in meaningful work and hardiness. Journal of Occupational Health Psychology, 6(1), 53-63. 
INTERNATIONAL JOURNAL OF ACADEMIC RESEARCH IN BUSINESS AND SOCIAL SCIENCES

Vol. 8, No. 11, Nov, 2018, E-ISSN: 2222-6990 @ 2018 HRMARS

Chalofsky, N., \& Krishna, V. (2009). Meaningfulness, commitment, and engagement: The intersection of a deeper level of intrinsic motivation. Advances in Developing Human Resources, 11(2), 189-203.

Chaudhary, R., Rangnekar, S., \& Barua, M. K. (2014). Organizational Climate, Climate Strength and Work Engagement. Procedia-Social and Behavioral Sciences, 133(2014), 291-303.

Chen, T.-Y., Chang, P.-L., \& Yeh, C.-W. (2003). The study of career needs, career development programmes and job satisfaction levels of R\&D personnel: the case of Taiwan. The International Journal of Human Resource Management, 14(6), 1001-1026.

Cordero, R., Ditomaso, N., \& Farris, G. F. (1994). Career development opportunities and likelihood of turnover among R\&D professionals. Engineering Management, IEEE Transactions on, 41(3), 223-232.

Demerouti, E., Bakker, A. B., Nachreiner, F., \& Schaufeli, W. B. (2001). The job demands-resources model of burnout. Journal of Applied Psychology, 86(3), 499-512.

Fairlie, P. (2011a). Meaningful Work, Employee Engagement, and Other Key Employee Outcomes: Implications for Human Resource Development. Advances in Developing Human Resources, 13(4), 508-525.

Fairlie, P. (2011b). Meaningful Work: A Sleeping Giant in the Context of Other Work Characteristics, Work Engagement, and Other Employee Outcomes. Paper presented at the The 119th Annual Convention of the American Psychological Association at

Hackman, J. R., \& Oldham, G. R. (1976). Motivation through the design of work: Test of a theory. Organizational Behavior and Human Performance, 16(2), 250-279.

Hair, F. J., Black, W. C., Rabin, B. J., Anderson, E. R. (2010). Multivariate Data Analysis (7 $7^{\text {th }}$ ed.). New Jersey: Pearson Hall.

Hobfoll, S. E. (1989). Conservation of resources: A new attempt at conceptualizing stress. American Psychologist, 44(3), 513-524.

Hoque, A. S. M. M., and Awang, Z., Jusoff, K., Salleh, F., and Muda, H. (2017). Social Business Efficiency: Instrument Development and Validation Procedure using Structural Equation Modelling, International Business Management, 11(1), 222-231.

Hoque, A. S. M. M., Awang, Z., and Salam, S. (2017a). The Effects of Relationship Marketing on Firm Performance: Small and Medium Enterprises (SMES) in Bangladesh, 1st International Conference on Business and Management (ICBM-2017), BRAC Business School (BBS), BRAC University, Dhaka, Bangladesh, September 21-22.

Hoque, A. S. M. M. and Awang, Z. (2016). The Sway of Entrepreneurial Marketing on Firm Performance: Case of Small and Medium Enterprises (SMEs) in Bangladesh, Terengganu International Business and Economics Conference (TiBEC-V), Terengganu, Universiti Teknologi Mara (UiTM), pp. 174-194.

James, J. B., McKechnie, S., \& Swanberg, J. (2011). Predicting employee engagement in an age-diverse retail workforce. Journal of Organizational Behavior, 32(2), 173-196.

Kashif, M., Samsi, S. Z. M., Awang, Z., \& Mohamad, M. (2016). EXQ: measurement of healthcare experience quality in Malaysian settings: A contextualist perspective. International Journal of Pharmaceutical and Healthcare Marketing, 10(1), 27-47. 
INTERNATIONAL JOURNAL OF ACADEMIC RESEARCH IN BUSINESS AND SOCIAL SCIENCES

Kraimer, M. L., Seibert, S. E., Wayne, S. J., Liden, R. C., \& Bravo, J. (2011). Antecedents and outcomes of organizational support for development: the critical role of career opportunities. Journal of Applied Psychology, 96(3), 485-500

Kuvaas, B. (2008). An exploration of how the employee-organization relationship affects the linkage between perception of developmental human resource practices and employee outcomes. Journal of Management Studies, 45(1), 1-25.

Ling Suan, C., \& Mohd Nasurdin, A. (2014). An empirical investigation into the influence of human resource management practices on work engagement: the case of customer-contact employees in Malaysia. International Journal of Culture, Tourism and Hospitality Research, $8(3), 345-360$.

Mohamad, M., Mohammad, M., Mat Ali, N. A., \& Awang, Z. (2016). The impact of life satisfaction on substance abuse: delinquency as a mediator. International Journal of Adolescence and Youth, 1-11.

Podsakoff, P. M., MacKenzie, S. B., Lee, J.-Y., \& Podsakoff, N. P. (2003). Common method biases in behavioral research: a critical review of the literature and recommended remedies. Journal of Applied Psychology, 88(5), 879-903.

Poon, J. M. (2013). Relationships among perceived career support, affective commitment, and work engagement. International Journal of Psychology, 48(6), 1148-1155.

Rich, B. L., Lepine, J. A., \& Crawford, E. R. (2010). Job engagement: Antecedents and effects on job performance. Academy of Management Journal, 53(3), 617-635.

Rosso, B. D., Dekas, K. H., \& Wrzesniewski, A. (2010). On the meaning of work: A theoretical integration and review. Research in Organizational Behavior, 30(2010), 91-127.

Rothmann, S., \& Buys, C. (2011). Job demands and resources, psychological conditions, religious coping and work engagement of reformed church ministers. Journal of Psychology in Africa, 21(2), 173-183.

Rothmann, S., \& Joubert, J. (2007). Job demands, job resources, burnout and work engagement of managers at platinum mine in the North West Province. South Africa Journal of Business Management, 38(3), 49-61.

Sahoo, C. K., \& Sahu, G. (2009). Effective employee engagement: The mantra of achieving organizational excellence. Management and Labour Studies, 34(1), 73-84.

Saks, A. M. (2006). Antecedents and consequences of employee engagement. Journal of Managerial Psychology, 21(7), 600-619.

Salanova, M., Agut, S., \& Peiró, J. M. (2005). Linking organizational resources and work engagement to employee performance and customer loyalty: the mediation of service climate. Journal of Applied Psychology, 90(6), 1217-1227.

Salanova, M., Lorente, L., Chambel, M. J., \& Martínez, I. M. (2011). Linking transformational leadership to nurses' extra-role performance: the mediating role of self-efficacy and work engagement. Journal of Advanced Nursing, 67(10), 2256-2266.

Schaufeli, W. B., Bakker, A. B., \& Salanova, M. (2006). The measurement of work engagement with a short questionnaire a cross-national study. Educational and Psychological Measurement, 66(4), 701-716. 
Schaufeli, W. B., Salanova, M., González-Romá, V., \& Bakker, A. B. (2002). The measurement of engagement and burnout: A two sample confirmatory factor analytic approach. Journal of Happiness Studies, 3(1), 71-92.

Shimazu, A., Schaufeli, W. B., Kubota, K., \& Kawakami, N. (2012). Do workaholism and work engagement predict employee well-being and performance in opposite directions? Industrial Health, 50, 316-321.

Shuck, B., \& Rose, K. (2013). Reframing employee engagement within the context of meaning and purpose: Implications for HRD. Advances in Developing Human Resources, 15(4), 341-355.

Sorenson, S. (2013). How employee engagement drives growth. Gallup Business Journal.

Steger, M. F., Dik, B. J., \& Duffy, R. D. (2012). Measuring meaningful work: The work and meaning inventory (WAMI). Journal of Career Assessment, 20(3), 322-337.

Stinger, C., Boverie, P. (2007). The role of meaning in work: A study of the transformational power of Meaningful work. Paper presented at the 7th International Transformative Learning Conference New Mexico. Transformative Learning: Issues of Difference and Diversity, (2007), 305-309

Swanberg, J. E., McKechnie, S. P., Ojha, M. U., \& James, J. B. (2011). Schedule control, supervisor support and work engagement: A winning combination for workers in hourly jobs? Journal of Vocational Behavior, 79(3), 613-624.

Thatcher, J. B., Liu, Y., Stepina, L. P., Goodman, J. M., \& Treadway, D. C. (2006). IT worker turnover: an empirical examination of intrinsic motivation. ACM SIGMIS Database, 37(2-3), 133-146.

Xanthopoulou, D., Bakker, A. B., \& Fischbach, A. (2013). Work engagement among employees facing emotional demands. Journal of Personnel Psychology. 12(2), 74-84.

Xanthopoulou, D., Bakker, A. B., Demerouti, E., \& Schaufeli, W. B. (2009). Work engagement and financial returns: A diary study on the role of job and personal resources. Journal of Occupational and Organizational Psychology, 82(1), 183-200.

Yusof, Y., Awang, Z., Jusoff, K., \& Ibrahim, Y. (2017). The influence of green practices by non-green hotels on customer satisfaction and loyalty in hotel and tourism industry. International Journal of Green Economics, 11(1), 1-14. 